\title{
In situ and post-synthesis
} immobilization of enzymes on nanocrystalline MOF platforms to yield active biocatalysts

\section{Victoria Gascón,†,‡ Elsa Castro-Miguel,‡ Manuel Díaz- García, RosaMBlanco and Manuel Sanchez-Sanchez*}

\author{
* Correspondence to: M Sánchez-Sánchez, Instituto de Catálisis y Petroleoquímica, \\ ICP-CSIC, C/Marie Curie, 2, 28049, Madrid, Spain. \\ Email:manuel.sanchez@icp.csic.es \\ † Current address: Chemical and Environmental Sciences, Synthesis and Solid \\ State Pharmaceutical Centre and Bernal Institute, University of Limerick, \\ Limerick, Ireland. \\ ¥ These two authors contributed equally to the lab work \\ Instituto de Catálisis y Petroleoquímica, ICP-CSIC,Madrid, Spain
}

\begin{abstract}
BACKGROUND: Very recently,metal-organic framework (MOF)materials have been postulated as emerging supports to achieve solid-state enzyme-contained biocatalysts. In this work, post-synthesis and in situ strategies to immobilize $\boldsymbol{\beta}$-glucosidase and laccase on differentMOFmaterialswere studied. The MOF-based supports, i.e. MIL-53(Al),NH2-MIL-53(Al) and Mg-MOF-74, were prepared under soft and sustainable conditions (roomtemperature and pHvalues compatiblewith enzymatic activity), allowing development of the in situ strategy.

RESULTS: In both post-synthesis and in situ approaches, the intercrystalline mesoporosity of the MOFbased support favored the immobilization efficiency or the specific activity. The latter expressed as units per milligram of immobilized enzyme was higher in the post-synthesis immobilization, whereas the biocatalysts prepared in situ gave much higher enzyme loading (over 85\%) and lower enzyme leaching (around 5\%). The in situ approach even worked in a non-aqueous (N,N-dimethylformamide) media inwhich the free enzymewas completely inactive. The immobilized enzymes are much larger than the structural pores of theMOFs.

CONCLUSIONS: Enzymes can be efficiently immobilized on nanocrystalline MOFs prepared under soft and sustainable conditions despite the supports lacking large enough pores to host the enzymes. The in situ approach is very efficient capturing enzymes and preserving some of their activity even under adverse conditions
\end{abstract}

\section{INTRODUCTION}

Obviating notable exceptions, $1-3$ catalysts designed by humans are far from being as selective as those given by nature, i.e. enzymes. Lability and solubility of enzymes limit their application and justify the efforts to immobilize enzymes with potential industrial interest in several supports.4-12 Numerous attempts to solve leaching and inactivation problems once immobilized have been reported.13-15 In the last decade, the use of siliceous ordered mesoporous materials as enzyme supports have provided new and improved properties to the resultant biocatalysts. Controlled pore size and surface chemistry together with regular structure give rise to high enzyme loadings, low diffusional limitations, high specific activities and scarce enzyme leaching even when the enzyme is non-covalently anchored to the supports.16-30 Metal-organic frameworks (MOFs) are porous materials that have strongly emerged in the last few years. They are composed of metal ions or clusters and organic linkers. The increasing number of applications in the last few years confirms the great potential of these new materials.31-35 More recently MOFs have been also used as a promising host matrix of enzyme immobilization.36-43 The most immediate approach has been to synthesize MOFs with pores large enough to host enzymes.44-48 However, this approach is far from being universal, as it entails two essential problems: (i) just a few (expensive and/or hard-to-prepare) MOF materials possess sufficiently large mesopores;45,47,48 and (ii) it is restricted to enzymes with small molecular dimensions that are able to be accommodated inside these pores.37,38,44 Nevertheless, very recently, some studies have opened the possibility of synthesizing enzyme-MOF biocatalysts without the requirement of hosting the enzymes within the structural pores of the MOF material, through either postsynthesis49-53 or in situ54-57 approaches. In other words, the formation of the enzyme-MOF composites can now take advantage of the extraordinary structural and compositional versatility as well as hierarchical porosity of MOF materials due to the use of a huge variety of organic functional moieties, metal nature, particle size, synthesis conditions, etc.41,58 In this work, we have compared post-synthesis and in situ methodologies to immobilize a given large-sized enzyme ( $\beta$-glucosidase) in two MOF materials (X-MIL-53(Al) with $\mathrm{X}=\mathrm{H}$ or $\mathrm{NH}_{2}$ ) at room temperature and inwater as the unique solvent.59-62 In these mild 
conditions the immobilized enzymes preserve at least part of their activity. The influence of different parameters such as intercrystalline mesoporosity of the MOF support, its organic functionalization, the systematic change of the synthesis conditions in the case of the in situ approach, etc. have been studied and discussed. Experiments involving other enzyme (laccase) or different MOF support (nanocrystalline Mg-MOF-74)61,62 are also presented.

Some strategies involving MOFs as enzyme supports reported so far are based on different approaches, such as: (i) the mixture of enzymes and MOF materials promotes undetermined kinds of interaction between enzymes and already formed MOFs;50,52 (ii) the quick and controlled growing of MOF crystals is able to randomly capture certain amounts of enzyme molecules;54,56,57,63 (iii) the enzymes (or other biomolecules) induce the formation of MOF-based coatings;55,64 (iv) the enzyme is part of the MOF framework acting as a node; 65,66 or ( $v$ ) the protection of the resultant enzyme-MOF composite using polymers (i.e. polydopamine) to enhance hydrophilicity and biocompatibility of the support and to increase the biocatalyst's stability and reusability.67-69 Our approach70 is based on trapping the enzymes into the relatively ordered mesopores created during the agglomeration/aggregation of MOF nanocrystals (intercrystalline mesoporosity).59-62 Unlike the in situ methods, our in situ approach does not generate embedded enzymes within the MOF crystals but they are possibly located in the hollow space between nanocrystals. Unlike the reported post-synthesis approaches, the possibility to encapsulate the enzymes within the intercrystalline mesoporosity is added to the simple interaction between the enzyme and the external surface of the MOF-based support. In the case of in situ immobilization approach, the possibility of preparing MOFs at room temperature and in water was taken as starting point,54,63 in order to preserve enzymatic activity. We have also explored the synthesis in a non-aqueous system, 55 namely DMF (N,N-dimethylformamide), and its effect on the activity of the free $\beta$-glucosidase and the MOF-enzyme composite. The colloidal-like nature of the synthesis media may avoid the escape of the enzymes from the support, giving very high immobilization efficiency for the in situ methodology. Since our system allows the enzyme immobilization by both post-synthesis and in situ approaches, this work compares both strategies in terms of immobilization efficiency, the specific catalytic activity or enzyme lixiviation.

\section{EXPERIMENTAL}

Detailed description of the as-received reactants and enzyme extracts, schemes of the different synthesis approaches, details of the characterization techniques as well as characterization and pretreatments of enzyme extracts, are given in Supporting information.

\section{Synthesis ofMOF materials}

Enzyme-free MOF materials were prepared according to the methods described elsewhere.59-62 In particular, MIL-53(Al) and $\mathrm{NH}_{2}-\mathrm{MIL}-53(\mathrm{Al})$ were prepared in water and at room temperature,59,60 whereas nanocrystalline Mg-MOF-74 was also prepared at room temperature but using N,N-

dimethylformamide (DMF) as solvent.61,62 These MOF materials were used as supports for the postsynthesis immobilization of enzymes and for comparison with the corresponding biocatalysts.

\section{Synthesis of enzyme-MOF biocatalysts}

$\beta$-glucosidase ( $\beta$-Glu) was selected to compare post-synthesis (immobilization after the synthesis of the material) and in situ (one-pot synthesis) immobilization methods. For the post-synthesis approach a nonfunctionalized MIL-53(AI) and a NH2-MIL-53(Al) materials were prepared in water at room temperature.60 Laccase (Lac)was also studied for comparative purposes because of its affinity for amino-functionalized materials.29 Post-synthesis immobilization: biocatalysts enzyme\#MOF Post-synthesis immobilization of either $\beta$-glucosidase or laccase on any of the three MOF materials (MIL-53(Al), NH2-MIL-53(Al) or MgMOF-74) was carried out by suspending $50 \mathrm{mg}$ of the MOF material in $10 \mathrm{~mL}$ of an enzyme aqueous solution in $50 \mathrm{mmol} \mathrm{L-1}$ acetic acid/sodium acetate buffer at pH 5.5 (Scheme S3). The suspension was kept under mild stirring for 0-27 hours (no further enzyme molecules were immobilized after $4 \mathrm{~h}$ ). The amount of enzyme immobilized onto the support was calculated by the difference between the respective activities of blank or suspension and the supernatant. Aliquots were withdrawn at given times, and the enzymatic activity of the blank, suspension and supernatant (after separating it by centrifugation) were assayed spectrophotometrically either by the hydrolysis of $\mathrm{p}$-Nitrophenyl glucoside ( $\mathrm{p}-\mathrm{NPG}$ ) by $\beta$-glucosidase or by the oxidation of the 2'azino-bis-(3-ethylbenzothiazoline-6-sulfonate (ABTS) di-ammonium salt by laccase (see Supporting information for details). The decrease in activity of the supernatant to a minimum and constant value indicated the end of the immobilization process. Protein content of the supernatant before and after the immobilization process was also measured in order to calculate the immobilization yield. Then, the suspension was filtered and the solid biocatalysts were washed with the same buffer used for immobilization. No protein was detected in the washing residues. The solid samples were then dried under vacuum and were stored at $4 \circ \mathrm{C}$. In order to determine the activity of the immobilized enzyme, $10 \mathrm{mg}$ of the corresponding biocatalysts were re-suspended in $0.5 \mathrm{~mL}$ of $50 \mathrm{mmol} \mathrm{L-1}$ acetate buffer $\mathrm{pH} 5.5$ or deionizedwater and catalytically analyzed following the processes described in Supporting information. All the measurements were performed at least three times and their averaged value was taken for shown results and discussion. 
In situ immobilization: biocatalysts $\beta$-Glu@MOF

The method to prepare the biocatalysts $\beta$-Glu@ $\mathrm{NH}_{2}-\mathrm{MIL}-53(\mathrm{Al})$ is similar to that described for thisMOFmaterial at roomtemperature in water, 59,60 but slightly modified by the incorporation of the enzyme extract and by the order of addition of the solutions to prevent the exposure of the enzymes to extreme $\mathrm{pH}$ values (Scheme S4). In a typical synthesis procedure, two clear aqueous solutions were prepared separately. The metal solution ( $\mathrm{pH} \sim 2.0$ ) was formed by $2.0 \mathrm{~g}$ of $\mathrm{Al}\left(\mathrm{NO}_{3}\right)_{3} \cdot 9 \mathrm{H}_{2} \mathrm{O}$ in $6.030 \mathrm{~g}$ of deionized

(a)

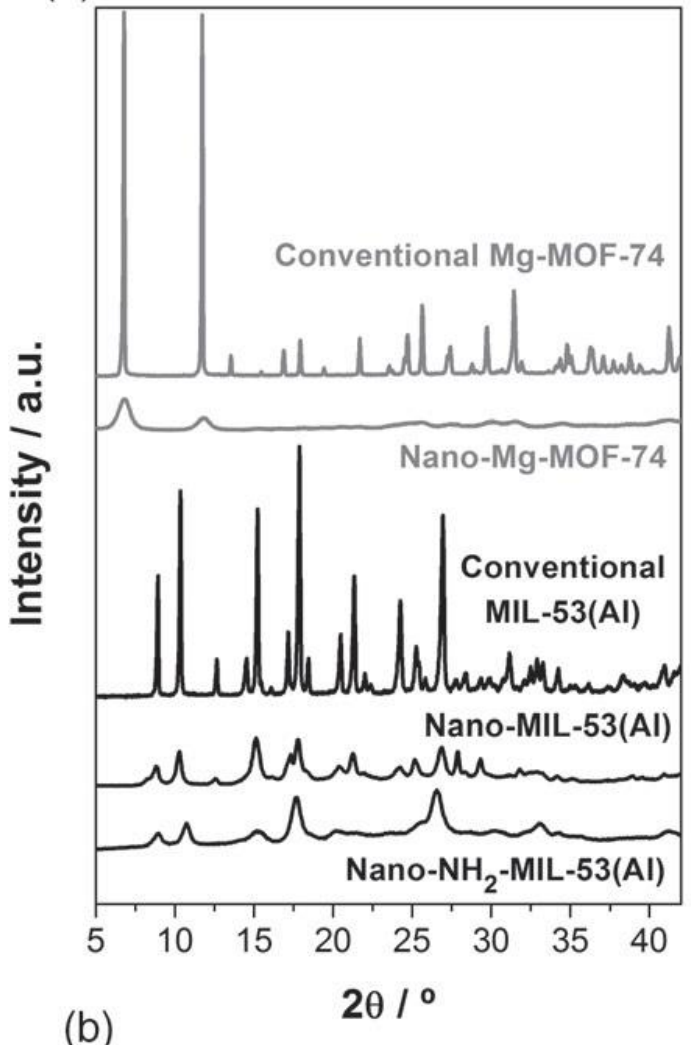

(C)

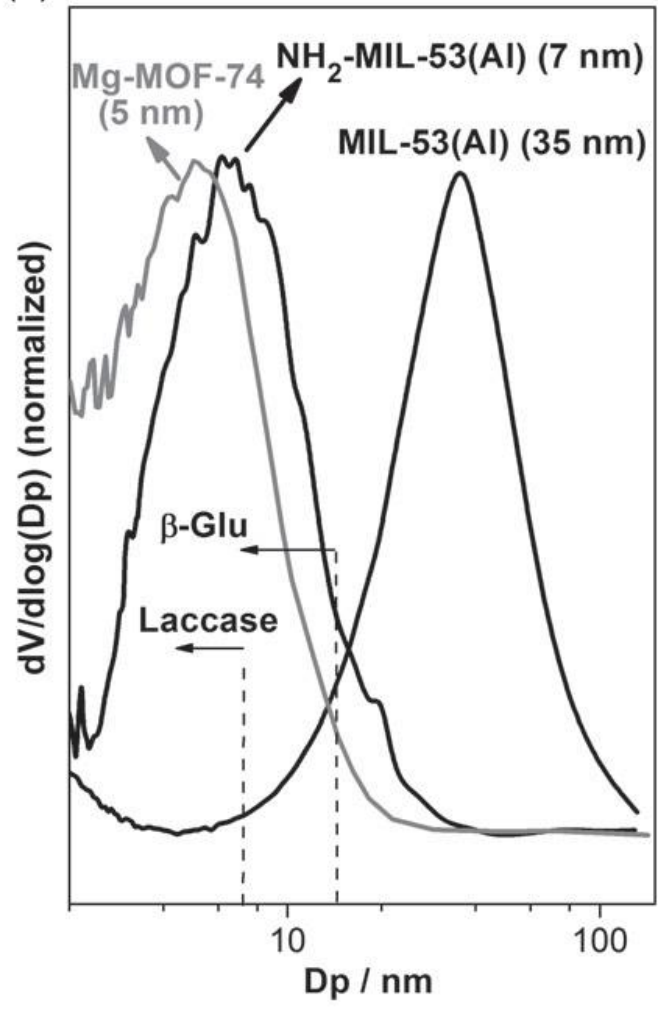

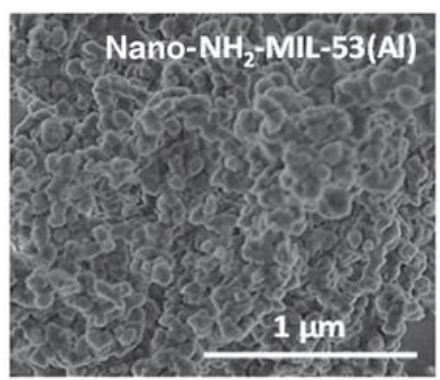
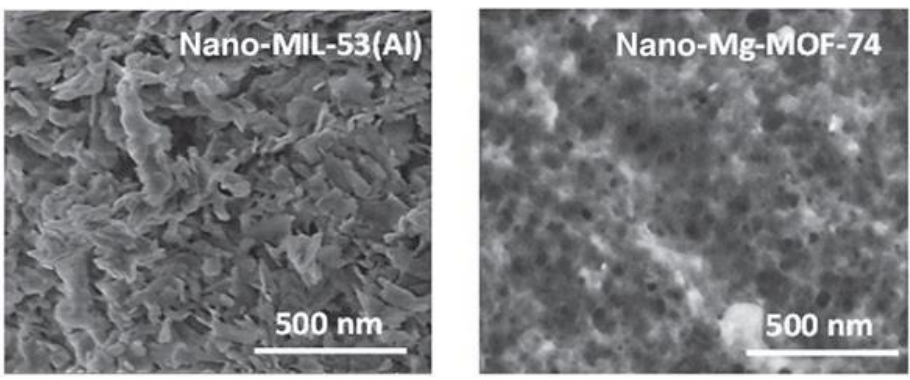

Figure 1. (a) PXRD patterns of the nanocrystalline MOFs used as support for enzyme immobilization: NH2-MIL-53(AI) (black line, at the bottom), MIL-53(Al)(also black), and Mg- MOF-74 (grey), comparedwith the conventional micrometersized MIL-53(Al) (black) and Mg-MOF-74 (grey). (b) Representative SEMimages of the three MOFs samples showing the intercrystalline mesoporosity. (c) Normalized pore size distribution curves arisen from the adsorptionbranches of the isotherms of the three nanocrystalline MOF materials. The size of the tested enzymes is indicated by dashed red lines.

water. The linker solution was prepared by dissolving $0.483 \mathrm{~g}$ 2-aminoterephtalic acid $\left(\mathrm{NH}_{2}-\mathrm{H}_{2} \mathrm{BDC}\right)$ in $13.246 \mathrm{~g}$ deionized water, assisted by one of the following three deprotonating agents: triethylamine (TEA, $0.538 \mathrm{~g})$, ammonium hydroxide $\left(\mathrm{NH}_{4} \mathrm{OH} 25 \%, 0.362 \mathrm{~g}\right)$ or sodium hydroxide ( $\left.\mathrm{NaOH} 1 \mathrm{~mol} \mathrm{~L}-1,5.206 \mathrm{~g}\right)$. The amount of water was corrected taking into account the water content, if any, contained in the deprotonating agent source. In the absence of these agents, the linker is not soluble, whereas in the presence of any of them the mixture becomes a clear solution after some time, from ca. 10min in the case of $\mathrm{NaOH}$ up to several hours in the case of $\mathrm{NH}_{4} \mathrm{OH}$. The $\mathrm{pH}$ of this solution is near neutral (around 6) and higher for stronger bases used as deprotonating agents. $\beta$-glucosidase extract $(2.75 \mathrm{~mL}$ of an extract concentration of $14.54 \mathrm{mg}$ protein $\mathrm{mL}-1$ of aqueous solution) is added over this linker solution, which entails 
a slight $\mathrm{pH}$ decrease (ca. 0.5 units) of the mixture. Later, the metal solution was dropwise added over the linker-enzyme solution under stirring at room temperature, causing the immediate appearance of a yellowish solid. The $\mathrm{pH}$ of the resultant suspension was rather acid, slightly above 3. Different aliquots were extracted from this suspension between $5 \mathrm{~min}$ and $48 \mathrm{~h}$. The solid biocatalysts were separated from this suspension by centrifugation (12 $500 \mathrm{rpm}$ for $1 \mathrm{~min}$ ), and they were denoted as $\beta$-Glu@NH2-MIL-53(Al)Base-time, where Base can be $\mathrm{TEA}, \mathrm{NH}_{3}$ or $\mathrm{NaOH}$, and time is substituted by the particular synthesis time $(1 \mathrm{~h}, 2 \mathrm{~h}, 48 \mathrm{~h}$, etc.) in the name of the sample.

In the preparation of the biocatalysts $\beta$-Glu@Mg-MOF-74, the metal solution is formed by dissolving 0.561 $\mathrm{g}$ of magnesium acetate tetrahydrate in $10 \mathrm{~g}$ of $\mathrm{N}, \mathrm{N}$-dimethylformamide (DMF). $0.5 \mathrm{~mL}$ of the $\beta$ glucosidase extract (14.54mgprotein $\mathrm{mL}-1$ in aqueous solution) were added over this solution. Next, the linker solution, which is composed of $0.2 \mathrm{~g}$ of 2,5-dihydroxyterephtalic acid (dhtp) in $10 \mathrm{~g}$ of DMF, was added dropwise over the metal-enzyme solution, giving rise to a yellow suspension. The biocatalysts, denoted as $\beta$-Glu@Mg-MOF-74-2h or -24h, were isolated by centrifugation (12 $500 \mathrm{rpm}$ for $45 \mathrm{~s}$ ) of the corresponding aliquots after 2 or $24 \mathrm{~h}$ reaction.

\section{Electrophoresis test of enzyme retention in biocatalysts}

\begin{tabular}{|c|c|c|c|c|}
\hline Biocatalyst & $\begin{array}{l}\text { Enzyme } \\
\text { immobiliz: } \% \%\end{array}$ & $\begin{array}{c}\text { Enzyme } \\
\text { loading }{ }^{/ /} / \mathrm{mg} \mathrm{g}^{-1}\end{array}$ & $\begin{array}{c}\text { Catalytic } \\
\text { activity } / \mathrm{Ug}^{-1}\end{array}$ & $\begin{array}{c}\text { Specific } \\
\text { activity }{ }^{3 /} / \mathrm{mg}^{-1}\end{array}$ \\
\hline f-GlueNH ${ }_{2}-$ MIL-53 & 12 & 0.6 & 11.4 & 19.30 \\
\hline A-GluғMIL-53 & 14.3 & 7.1 & 30.0 & 4.22 \\
\hline F-GlutMS-3030 & 8.8 & 4.4 & 14 & 3.2 \\
\hline LactNH $_{2}-$ MIL-53 & 20.4 & 10.2 & 3.1 & 0.30 \\
\hline LactMLL-53 & 10.7 & 5.3 & 0.5 & 0.10 \\
\hline LactMg-MOF-74 & 32.8 & 16.4 & 2.6 & 0.16 \\
\hline \multicolumn{5}{|c|}{ 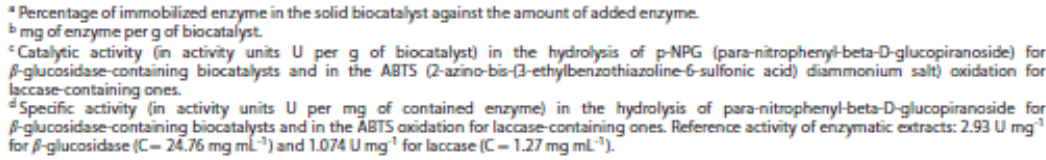 } \\
\hline
\end{tabular}

The efficiency of the enzyme encapsulation was studied by means of SDS-PAGE electrophoresis. Since the solid samples are not suitable for electrophoresis, the enzyme was forced to leave the pores by the following procedure. First, the biocatalystswere suspended in the electrophoresis buffer solution (containing sodium dodecyl sulfate,mercaptoethanol, bromophenol blue, tris buffer $\mathrm{pH} 6.8$ and glycerol) and boiled for $10 \mathrm{~min}$. In such denaturing conditions including the split of disulfide bonds, the tertiary structure of the protein should be lost and the random coil chain should then be easily released from the pores. The supernatants of these suspensions were withdrawn and run in $10 \%$ SDS-PAGE electrophoresis.

\section{Leaching tests}

The resistance of the enzyme to leaching from the support was studied under conditions that presumably favor the release of the protein, namely high dilution and low ionic strength. The biocatalysts were incubated in $50 \mathrm{mmol} \mathrm{L-1}$ phosphoric acid/trisodium citrate buffer at $\mathrm{pH} 5.0$ with a content of $1.25 \mathrm{mg}$ of solid permL of buffer. Enzyme leachingwas calculated by monitoring the appearance of protein in the supernatant utilizing the Bradford assay. 71

\section{RESULTS AND DISCUSSION}

The results and discussion section has been divided in two differentmain sub-sections corresponding to the post-synthesis (immobilization of the enzyme in the pre-existent support) and in situ (the enzyme is present during the formation of the MOF-based support) strategies. In each approach, different parameters have been systematically varied. The advantages and disadvantages of the post-synthesis vs the in situ methods are discussed in a third sub-section.

\section{Post-synthesis immobilization: biocatalysts Enzyme\#MOF}

Figure 1 shows some characterization results of the three MOF-based nanomaterials used as supports: MIL-53(Al), NH2-MIL-53(Al) and Mg-MOF-74. The total surface area of all these materials is very high (near $1000 \mathrm{~m}_{2} \mathrm{~g}-1$ ),60,62 but most of it corresponds to MOF structural micropores, which cannot host proteins. Only the external surface ranging between 90 and $100 \mathrm{~m}_{2} \mathrm{~g}-1$ in the three MOF samples,60,62 is available for that aim. MIL-53(Al) and $\mathrm{NH}_{2}-\mathrm{MIL}-53(\mathrm{Al})$ having very different interparticle mesopore size distribution,60 were used to study the effect of confinement of the enzyme. These materials were also used to study the influence of organic functionalization, particularly the affinity of laccase for amino groups of the supports.29,72 On the other hand, Mg-MOF-74 could provide some information about the possible role of the open metal sites in the enzyme immobilization. From a sustainable point of view, it is remarkable that all three materials were prepared at room temperature according to two recent publications of our group.59-62 
The nanocrystallinity of the samples can be inferred from the powder XRD (X-ray diffraction) patterns compared with those of the corresponding conventional micrometer-sized homologues (Fig. 1(a)). Such nanocrystalline nature of the supports acts as driving force to either agglomerate59,60 or aggregate62 the crystalline nanocrystals in particles of several microns (Fig. 1(b)). The fused particles possess relatively ordered intercrystralline mesoporosity as indicated by pore size distribution (Fig. 1(c)) and visualized by SEM images (Fig. 1(b)). The maximum of the PSD (pore size distribution) curves forNH2-MIL-53(Al) (7 $\mathrm{nm})$ and Mg-MOF-74 (5 nm) materials (Fig. 1(c)) is below the dimensions of the studied enzymes $(6.3 \mathrm{~nm}$ $\times 7.2 \mathrm{~nm} \times 8.9 \mathrm{~nm}$ for laccase,29 and $12.3 \mathrm{~nm} \times 10.7 \mathrm{~nm} \times 8.1 \mathrm{nmfor} \square$-glucosidase according to the same estimation method applied to laccase). Furthermore, it iswell known that the BJH method underestimates the pore dimension by at least $20 \% .73,74$ In addition, Mg-MOF-74 and NH2-MIL-53(Al) materials contain certain intercrystalline mesopores as large as 20 and $30 \mathrm{~nm}$, respectively, (Fig. 1(c)). Therefore both MOF-based supports possess some mesopores large enough to accommodate these enzymes.

Table 1 shows some relevant data of the biocatalysts generated by the post-synthesis immobilization procedures (enzyme\#MOF). Entries 1, 2, 4 and 5 of Table 1 compare the immobilization of the enzymes $\square$-glucosidase and laccase on MIL-53(Al) and on its amino-functionalized counterpart materials. MIL53(Al) was able to immobilize $14.3 \%$ of $\square$-Glu (Fig. 1(c)), probably due to their intercrystallinemesoporosity. However, this dimeric protein is too large to enter into most of the pores of $\mathrm{NH}_{2}-\mathrm{MIL}-53(\mathrm{Al})$ (Fig. 1(c)), so no improvement in the immobilization yield was observed upon functionalization with amine groups. In this case the immobilization yield was very low but an unexpected effect of increased activity of the enzyme was observed, which could possibly be related to the removal of some inhibitors present in the enzyme extract. Some other recent studies in which enzymes have been immobilized in MOF supports, also found an increase of activity per enzymemolecule (unpublished results). A commercial amorphous (MS-3030) amine-functionalized mesoporous silica (MS-3030) support with surface area of $236 \mathrm{~m} 2 \mathrm{~g}-1$ and an average pore size of $29 \mathrm{~nm}$ was also used to immobilize $\beta$ glucosidase for comparative purposes. As shown in Table 1, values of enzyme loading and catalytic activity obtained with this support were lower than those with $\beta$-Glu\#MOF. double on $\mathrm{NH}_{2}-\mathrm{MIL}_{\text {- }}$ $53(\mathrm{Al})$ than onMIL-53(Al), probably due to the smaller size of laccase (with a monomeric protein structure) and also because laccase does not show the extensive glycosylation of beta-glucosidase, which might cause steric hindrance.75 In addition, the interaction between laccase and the amino groups favors the immobilization of this enzyme as shownby entries 4 and 5 of Table 1, which indicate that immobilization yield is double in amino-functionalized MOF. The importance of the confinement is ratified in the laccase immobilization procedure over the $\mathrm{NH}_{2}$-free Mg-MOF-74 material (entry 6 of Table 1). The presence of open metal $(\mathrm{Mg})$ sites in this MOF 60 could play a role as important as that of amino groups in the $\mathrm{Lac \# NH}_{2}-$ MIL-53(AI) biocatalyst (entry 4 of Table 1$)$.

In summary, the post-synthesis enzyme immobilization over nanocrystalline MOF-based supports opens up numerous possibilities of tailoring the properties of the support (porosity, organic functionalization, metal coordination, etc.) and seems to be a promising strategy to immobilize enzymes. The preservation of catalytic activity indicates that the protein structure ismaintained, corroborating the good prospects of the enzyme immobilization on these sustainable MOFs. These results encourage working on the improvement of both enzyme loadings and specific activity.

\section{In situ immobilization: biocatalysts $\beta$-Glu@MOF}

Our methodology entails an indirect and extra industrial advantage, i.e. the sustainability of the process, since these materials were prepared at room temperature.59,60 That aspect also inspires a strategy to immobilize enzymes on MOF materials by an in situ approach, which has been reported to have some advantages/singularities in comparison with the post-synthesis approaches for some other supports.20,41,76 Moreover, in other reported in situ immobilization systems, the enzymes, far from being mere spectators, can have active roles such as template in the generated pores.20 Based on these two premises, the following in situ studies focus on the immobilization of the large enzyme $\beta$-glucosidase on both $\mathrm{NH}_{2}-\mathrm{MIL}-53(\mathrm{Al})$ and $\mathrm{Mg}-\mathrm{MOF}-74$ materials.

\section{In situ immobilization of $\boldsymbol{\beta}$-glucosidase on $\mathrm{NH}_{2}-\mathrm{MIL}-53(\mathrm{Al})$}

Our reportedmethod to prepare carboxylate-basedMOFs at room temperature and in water as the unique solvent implies starting from two solutions of very different pH values.59,60 The choice of the solution in which the enzyme is added as well as the order of addition of the solutions to form the final mixture, are crucial to optimize the preservation of catalytic activity of the enzyme, which could become irreversibly affected by extreme acidity/basicity of the media. On the other hand the linker and metal solutions form a precipitate as soon as they are mixed, so the enzymatic extract must be ideally present in this medium in order to favor the enzyme immobilization. For these two reasons, the enzyme was added in the linker solution previously and carefully prepared in order to reach $\mathrm{pH}$ values (not higher than 6) just above the pka2 value of the amino-terephtalic/amino-terephthalate system. The metal solution was added over the linker solution containing the enzyme and not the opposite as usually reported.59,60 Thus, the enzyme was present from the first moment of the formation of the MOF material and it does not suffer the extreme acidic conditions of the metal solution ( $\mathrm{pH}$ ca. 2). 
The role of the chemical base is to deprotonate the carboxylic groups of the linker sources, 59,60 and it is the only chemical that is not present in the final MOF material.

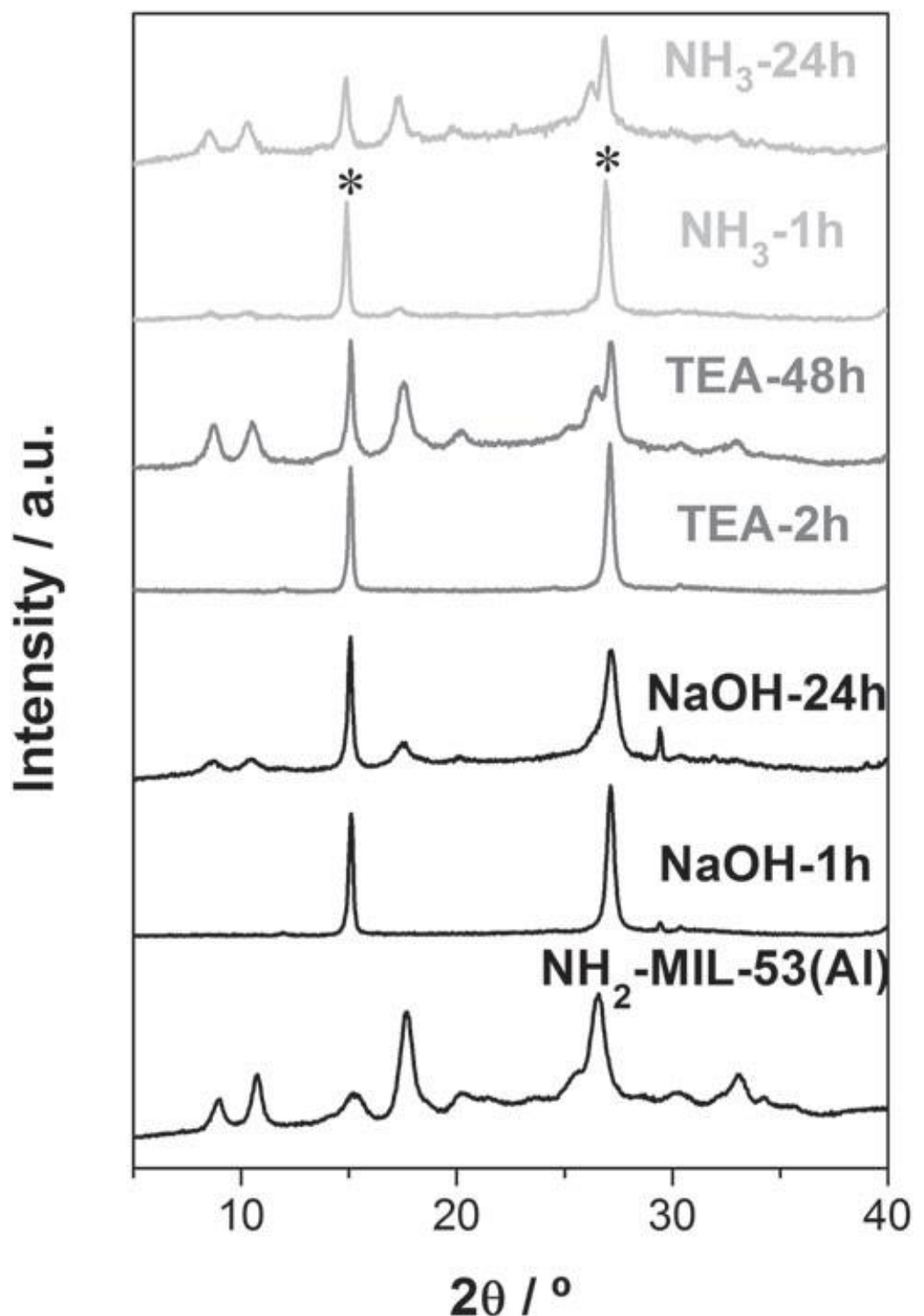

Figure 2. Normalized XRD patterns of the biocatalysts $\beta$-Glu@NH2-MIL-53(Al) prepared with different bases $(\mathrm{NaOH}$, TEA or $\mathrm{NH}_{3}$ ) and after different synthesis times (from $1 \mathrm{~h}$ to $48 \mathrm{~h}$ ). The pattern of the enzyme-free NH2-MIL-53(Al) is also shown for comparison purposes. The two most intense reflections of the protonated linker H2BDC are indicatedwith asterisks over the top pattern.

However, the nature of that base could have a key influence on the enzyme activity, so various deprotonating agentswere tested, i.e. $\mathrm{NaOH}$, trimethylamine (TEA) and $\mathrm{NH}_{4} \mathrm{OH}$. Figure 2 shows the XRD patterns of the six biocatalysts $\beta$-Glu@NH2-MIL-53(Al) prepared with three deprotonating agents and after two synthesis times. They are compared with the XRD pattern of an enzyme-free nanocrystalline $\mathrm{NH}_{2}-\mathrm{MIL}-53(\mathrm{Al})$ material, also prepared at room temperature according to the method described elsewhere.59,60 The diffractograms are dominated by two phases: the protonated organic linker $\mathrm{NH}_{2}-\mathrm{H}_{2} \mathrm{BDC}$ and the desired nanocrystalline $\mathrm{NH}_{2}-\mathrm{MIL}-53(\mathrm{Al})$ material. The preparation of X-MIL$53(\mathrm{Al})$ materials at room temperature and in water assisted by non-strong bases as deprotonating agents (TEA or $\mathrm{NH}_{3}$ ) is a novelty of this work.

In good agreement with the evolution of crystalline phases along the synthesis time in similar systems,59,60 $\mathrm{NH}_{2}-\mathrm{H}_{2} \mathrm{BDC}$ is the predominant phase at short times, whereas the proportion of the $\mathrm{NH}_{2}-\mathrm{MIL}-53(\mathrm{Al})$ phase increases at the expense of the former with synthesis time. The formation of the $\mathrm{NH}_{2}-\mathrm{H}_{2} \mathrm{BDC}$ is reasonable considering that the final $\mathrm{pH}$ (around 3) of themixture is lower than the pKa2 of the organic linker (4.8). After the tested times (not longer than $48 \mathrm{~h}$ ), the MOF phase becomes dominant. Surprisingly, the amount of $\mathrm{NH}_{2}-\mathrm{H}_{2} \mathrm{BDC}$ phase is higher than that of the MOF material when the strongest base $\mathrm{NaOH}$ is used as the deprotonating agent. 


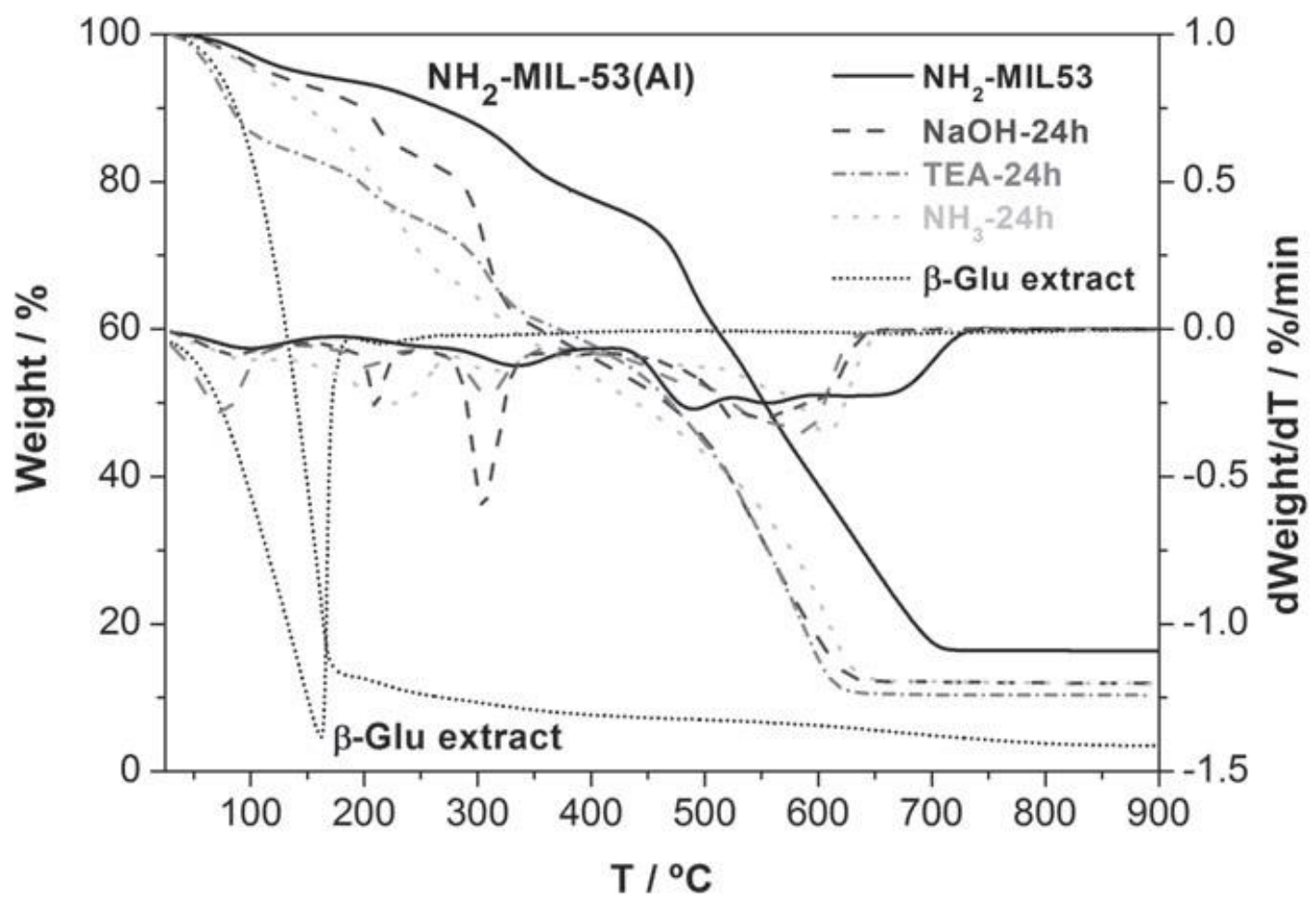

Figure 3. TGA (left Y-axis) and DTG (right $\mathrm{Y}$-axis) curves of the $\mathrm{NH}_{2}-\mathrm{MIL}-53(\mathrm{Al})$ material (solid black lines), the $\beta$-Glu extract (dot black lines) and the biocatalysts $\beta$-Glu@NH2-MIL-53(Al) prepared with different base ( $\mathrm{NaOH}, \mathrm{TEA}$ or $\mathrm{NH} 3$ ) at long times.

The presence of the enzyme in these biocatalysts was inferred by different characterization techniques. Figure 3 shows the thermogravimetric curves and the corresponding derivatives of some biocatalysts compared with those of the enzymatic extract and the enzyme-free NH2-MIL-53(Al) material. The TGA plot of the $\beta$-Glu extract is evidently dominated by a large weight loss ofwater, and it contains some other minor weight losses. One of them is abrupt enough to be detected in the derivative curve. That loss was centered at $217 \circ \mathrm{C}$ and tentatively attributed to the enzyme as described by others authors.54,57 Validating that assignation, the TGA curve of the enzyme-free MOF material does not show any loss close to that temperature, whereas the TGA plots of all $\beta$-Glu-containing biocatalysts show sharp weight losses centered in the range $205-215 \circ \mathrm{C}$, which must be related to the presence of the enzyme. The relatively low weight losses and the presumable overlap of this loss with that of $\mathrm{NH}_{3}$ in the $\beta$-Glu@NH $\mathrm{N}_{2}-\mathrm{MIL}-53(\mathrm{Al})-\mathrm{NH}_{3}$ biocatalysts discouraged us to quantify the enzymatic charge with this technique. That quantification was accurately achieved by means of the Bradford method (Table 1). Nevertheless, TGA provides qualitative and quick valuable information that could even become quantitative in other systems. TGA could also provide some extra information about: (i) the thermal stability of the MOF-based support through the linker decomposition temperature; (ii) the MOF composition, through the linker loss/residual weight ratio; (iii) the possible presence of impurities, such as the undesired protonated linker; or (iv) the possible interaction enzyme-MOF. Thus, from the TGA/DTG curves of the biocatalysts $\beta$-Glu@NH2-MIL$53(\mathrm{Al})$, it is evident that the MOF supports have similar Al/linker ratio and similar stability to those of the enzyme-free $\mathrm{NH}_{2}-\mathrm{MIL}-53(\mathrm{Al})$ material irrespective of the deprotonating agent nature, althoughwith different linker decomposition pattern. Moreover, the amount of deprotonated linker (weight loss slightly above 300 -C) 60 is in good agreement with the phase identification/quantification by means of powder XRD (Fig. 2). CHNS chemical analysis was also used to prove the presence of $\beta$-glucosidase in the biocatalysts. Although the presence of $\mathrm{N}$ atoms in the amino-containing supports prevents the use of $\mathrm{N}$ content as an enzymatic probe, sulfur content $(\mathrm{S})$ could however play that role. Indeed, the $\mathrm{NH}_{2}-\mathrm{MIL}-53(\mathrm{Al})$ material was completely free of $S$ whereas the enzymatic extract (concentration of $14.54 \mathrm{mg}$ of enzyme per $\mathrm{mL}$ of solution) gave a $\mathrm{S}$ content of $0.24 \mathrm{wt}$.\%. The measured $\mathrm{S}$ content of the biocatalysts $\beta$-Glu@NH2-MIL53(Al)- $\mathrm{NaOH}-24 \mathrm{~h},-\mathrm{TEA}-48 \mathrm{~h}$ and $\mathrm{NH}_{3}-24 \mathrm{~h}$ were $0.17,0.19$, and $0.15 \mathrm{wt} \%$, respectively, in good qualitative agreement with the enzyme content estimated by the Bradford method (Table 2). The series of the $\beta$ Glu@NH2-MIL-53(Al) biocatalysts were tested in the hydrolysis of para-nitrophenyl-beta-D-

glucopiranoside (p-NPG) (Table 2, Scheme S1). Regardless of the used deprotonating agent, the capacity of the solid support to immobilize the enzyme $\beta$-glucosidase increases with synthesis time, reaching an 
immobilization percentages of almost $100 \%$ of the enzyme after $24 \mathrm{~h}$ (Table 2 ). We think that a combination of two factors contributes to the high enzyme retention: (i) the colloidal-like nature of the MOF suspension preventing enzyme release; 41 and (ii) a favorable enzyme-MOF interaction. 77 At shorter times, the immobilization yield is much lower, which must be related with the low proportion of $\mathrm{NH}_{2}-\mathrm{MIL}-53(\mathrm{Al})$ phase with respect to the linker $\mathrm{NH}_{2}-\mathrm{H}_{2} \mathrm{BDC}$ (Fig. 2). In other words, the MOF material, and not the protonated linker, is responsible for retaining the enzyme molecules. Despite none of our samples being purely MOF phase, all of them succeed in retaining relatively high enzyme loadings. The activity of the biocatalysts prepared for longer synthesis timeswas higher because of the higher enzyme loadings (Table 2). But the reaction conditions and/or diffusional problems of reactants not reaching more hindered enzyme caused a progressive inactivation of the $\beta$-glucosidase. So the specific activity (activity per milligram of immobilized enzyme) was lower (Table 2). It should be noted that, unlike the post-synthesis immobilization procedure, the in situ synthesis conditions had to be designed to favor formation of the nanocrystalline MOF and not only to maintain enzyme activity. That is why longer experiments were not planned since 24 or $48 \mathrm{~h}$ were enough to immobilize almost the whole amount of the enzyme present. $\mathrm{NaOH}$ is the only deprotonating agent reported so far for the synthesis of X-MIL-53(Al) materials under these conditions.59,60 However, the biocatalysts prepared in the presence of $\mathrm{NaOH}$ gave the lowest catalytic activity. This could be in part due to the high basic character of the solution in which the enzyme is added. In situ immobilization of $\beta$-glucosidase on Mg-MOF-74 Mg-MOF-74 was chosen as an in situ support to study a possible template role of the intercrystalline mesopores played by the enzyme because: (i) the relative narrow mesopore size distribution in Mg-MOF-74 (Figure 1), with a maximum smaller than the $\beta$-glucosidase dimensions; and (ii) the high sensitivity of the textural properties of the M-MOF-74 nanomaterials to any minor change in the synthesis conditions such as metal source solubility or nature of the metal anion source.62 However, the organic medium in which the nanocrystalline Mg-MOF-74 is prepared, i.e. N,N-dimethylformamide (DMF), leads to fast, complete and irreversible inactivation of the free $\beta$-glucosidase.

Figure 4 compares the powder XRD patterns, the $\mathrm{N}_{2}$ adsorption/ desorption isotherms at $-196 \circ \mathrm{C}$ and the pore size distribution (PSD) curves of the enzyme-free nanocrystallineMg-MOF-7461 and the biocatalyst $\beta$ Glu@MOF-74, both obtained after $24 \mathrm{~h}$ synthesis time. XRD patterns indicate that MOF-74 is the unique detected crystalline phase irrespective of the presence/absence of $\beta$-glucosidase. However, the presence of this enzyme noticeably affects the nature of the phase, as the XRD peaks are broader,more intense and noisier, which is probably related to its smaller crystal size and lower crystal size homogeneity. Nevertheless, the biocatalyst is almost as porous as the $\beta$-glucosidase-free MOF-74 sample (993 vs $1007 \mathrm{~m}_{2}$ g-1, respectively) but having different features in the mesopore region (Fig. 4(b) and (c)). The pore size distribution of the biocatalyst is broader and shifted to larger pores compared with Mg-MOF-74, suggesting that certain intercrystalline mesopores are able to accommodate $\beta$-glucosidase. This experimental fact suggests that enzyme might have a template-like role that would favor the consistence of the biocatalyst presumably through non-covalent interactions and minimizing the enzyme leaching. In this sense, it has been demonstrated recently that bio-macromolecules can induce the formation of MOF coatings around them. $36,40,55,56$

(a)

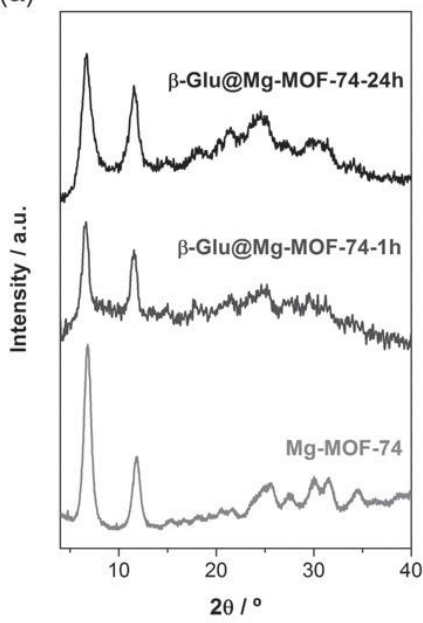

(b)

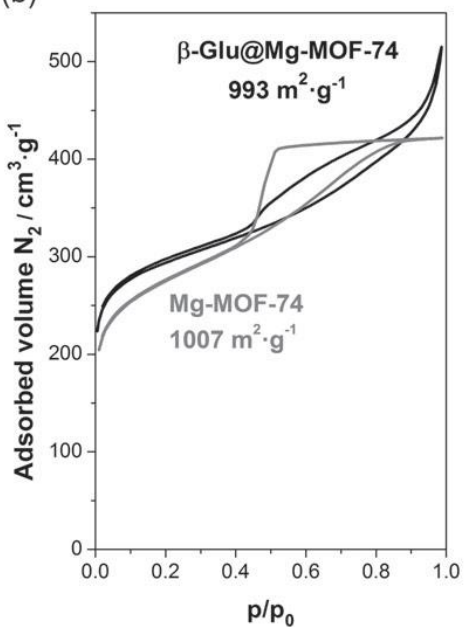

(c)

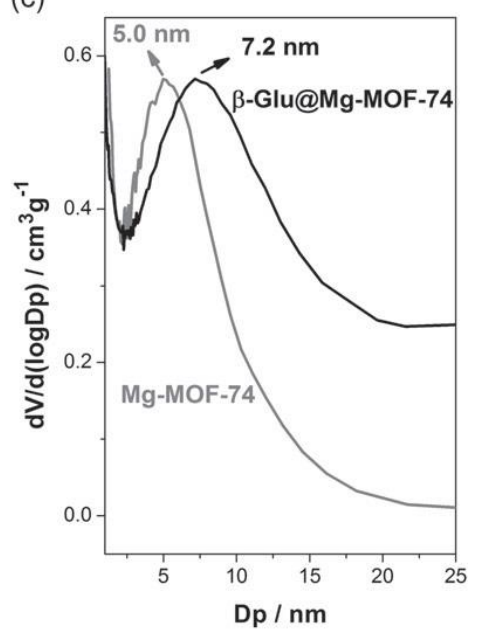

Figure 4. (a) Normalized XRD patterns of the Mg-MOF-74 and the biocatalysts $\beta$-Glu@Mg-MOF-74 after $1 \mathrm{~h}$ and $24 \mathrm{~h}$ of preparation. (b) and (c) N2 adsorption/desorption isotherms at $-196{ }^{\circ} \mathrm{C}$ and the PSD curves arisen from the adsorption branches, respectively, of the enzyme-free (grey) and $\beta$-glucosidase-containing (black) Mg-MOF-74 after 24 $\mathrm{h}$ of synthesis time. Estimated BET areas and PSD maxima are indicated in (b) and (c), respectively 


\begin{tabular}{|c|c|c|c|c|}
\hline $\begin{array}{l}\text { Biocatalyst } \\
\text { P-Glug NH }{ }_{2} \text {-MIL-53 }\end{array}$ & $\begin{array}{l}\text { Enzyme } \\
\text { immobliz:\% } \%\end{array}$ & $\begin{array}{l}\text { Enzyme } \\
\text { losding//mg } g^{-1}\end{array}$ & $\begin{array}{c}\text { Catalytic } \\
\text { activity } \text { g }^{-1}\end{array}$ & $\begin{array}{c}\text { Specific } \\
\text { sctivity }^{d} / \mathrm{mgg}^{-1}\end{array}$ \\
\hline $\mathrm{NaOH}-\mathrm{lh}$ & 33 & 28 & 6 & 0.21 \\
\hline $\mathrm{NaOH}-24 \mathrm{~h}$ & 96 & 79 & 31 & 0.39 \\
\hline TEA-2h & 17 & 18 & 40 & 2.17 \\
\hline TEA-48h & 99 & 108 & 94 & 0.87 \\
\hline $\mathrm{NH}_{3}-\mathrm{lh}$ & 5 & 7 & 18 & 2.57 \\
\hline $\mathrm{NH}_{3}-24 \mathrm{~h}$ & 98 & 56 & 51 & 0.91 \\
\hline \multicolumn{5}{|c|}{ 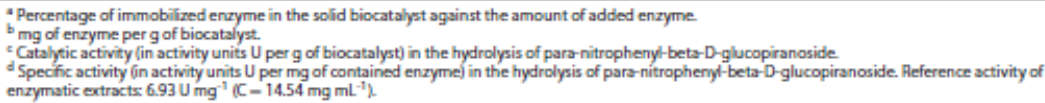 } \\
\hline
\end{tabular}

These biocatalysts were tested in the hydrolysis of the substrate p-NPG to p-nitrophenol (Table 3). Catalytic activity of the enzymatic extract was instantly and fully lost in DMF. Remarkably, both MOFsupported biocatalysts prepared in situ in DMF for 1 and $24 \mathrm{~h}$ catalyzed the reaction to some extent, which means that the MOF support protects $\beta$-glucosidase activity from total inactivation in this adverse medium. 55 High value applications can be derived from this result since the range of industrial reactions catalyzed by enzymes might be expanded to some organic media.35 The catalytic activity of these biocatalysts noticeably decreases with time, as expected because of the adverse immobilization media for the enzyme.78 Nevertheless, after $24 \mathrm{~h}$ of synthesis, the solid biocatalyst maintains almost half the conversion reached after $1 \mathrm{~h}$. Although the catalytic activity of these biocatalysts is rather limited, the one obtained after $1 \mathrm{~h}$ gave the same activity as $\beta$-Glu@NH2-MIL-53(Al)-NH3-1h, and three times higher activity than that of $\beta$-Glu@NH2-MIL-53(Al)-NaOH-1h (Table 2), both prepared in aqueousmediumover the sametime. Of course, that comparison is in favor of the MOF-74-supported biocatalyst as, unlike its counterparts, this sample contains MOF as the unique crystalline phase detected by XRD. This fact promisingly leaves some room for improvement of the catalytic activity at even shorter times. On the other hand, once again, it certifies that the MOF phase is the only (or, at least, the foremost) responsible solid phase in the immobilization of enzymes. Likewise, it suggests that both the MOF formation and enzyme immobilization occur simultaneously, and that the enzyme-MOF interconnection is favored in the in situ strategy.

The easiest characterization test to prove the presence of enzyme within the samples $\beta$-Glu@Mg-MOF-74 was the electrophoresis under enzyme denaturant conditions by SDS-PAGE.79 Figure 5 shows the electrophoresis gel images of the biocatalysts $\beta$-Glu@Mg-MOF-74-1 h and $-24 \mathrm{~h}$ compared with the $\beta$ glucosidase extract. The widest band in the electrophoresis gel of the enzymatic extract corresponds to the monomer of $\beta$-glucosidase $(120 \mathrm{kDa}$ ), whereas the rest of the signals must be attributed to other proteins present in the extract. Before immobilization the enzymatic extract was ultrafiltrated as shown in Figure S1, so only a major band of $120 \mathrm{kDa}$ corresponding to the monomer of $\beta$-glucosidase remains, whereas some minor bands can be neglected. The gels of both biocatalysts $\beta$-Glu@Mg-MOF-74-1h and -24h also show the main signal of $120 \mathrm{kDa}$, undoubtedly evidencing the presence of the enzyme $\beta$-glucosidase in these biocatalysts. Sulfur content of the biocatalysts $\beta$-Glu@Mg-MOF-74-24h (0.13 wt\%) compared with those of the $\beta$-glucosidase extract $(0.24 \mathrm{wt} \%$ for a concentration of $14.54 \mathrm{mg} \mathrm{mL}-1)$ and of the enzyme-free Mg-MOF-74 (0.00 wt\%) gave extra qualitative but unequivocal evidence of the presence of the enzyme in these Mg-MOF-74-supported biocatalysts.

\begin{tabular}{|c|c|c|c|c|}
\hline Biocatalyst/8-GlueMg-MOF-74 & $\begin{array}{c}\text { Enzyme } \\
\text { immobiliz"/\% }\end{array}$ & $\begin{array}{c}\text { Enzyme } \\
\text { bading }\end{array}$ & $\begin{array}{c}\text { Catalytic } \\
\text { sctivity } \\
\text { sil g' }\end{array}$ & $\begin{array}{c}\text { Specific } \\
\text { sctivity } / \mathrm{Ug} \mathrm{mg}^{-1}\end{array}$ \\
\hline ih & 86 & 112 & 18 & 0.16 \\
\hline $24 \mathrm{~h}$ & 86 & 113 & 7 & 0.07 \\
\hline Extract $\left(14.54 \mathrm{mg} \mathrm{mL}^{-1}\right)$ & 0 & 0 & 0 & 0 \\
\hline
\end{tabular}


SDS-PAGE $10 \%$

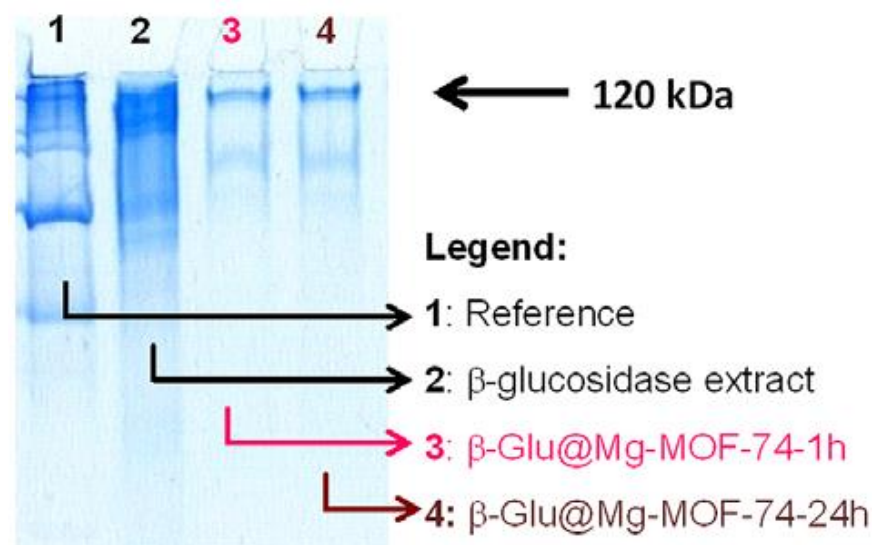

Figure 5. Electrophoresis gel of (from the left to the right): (a) a protein marker, (b) $\beta$-glucosidase extract (concentration $14.54 \mathrm{mgmL}-1$ ), (c) biocatalyst $\beta$-Glu@Mg-MOF-74-1h, and (d) biocatalyst $\beta$-Glu@Mg-MOF-74-24h

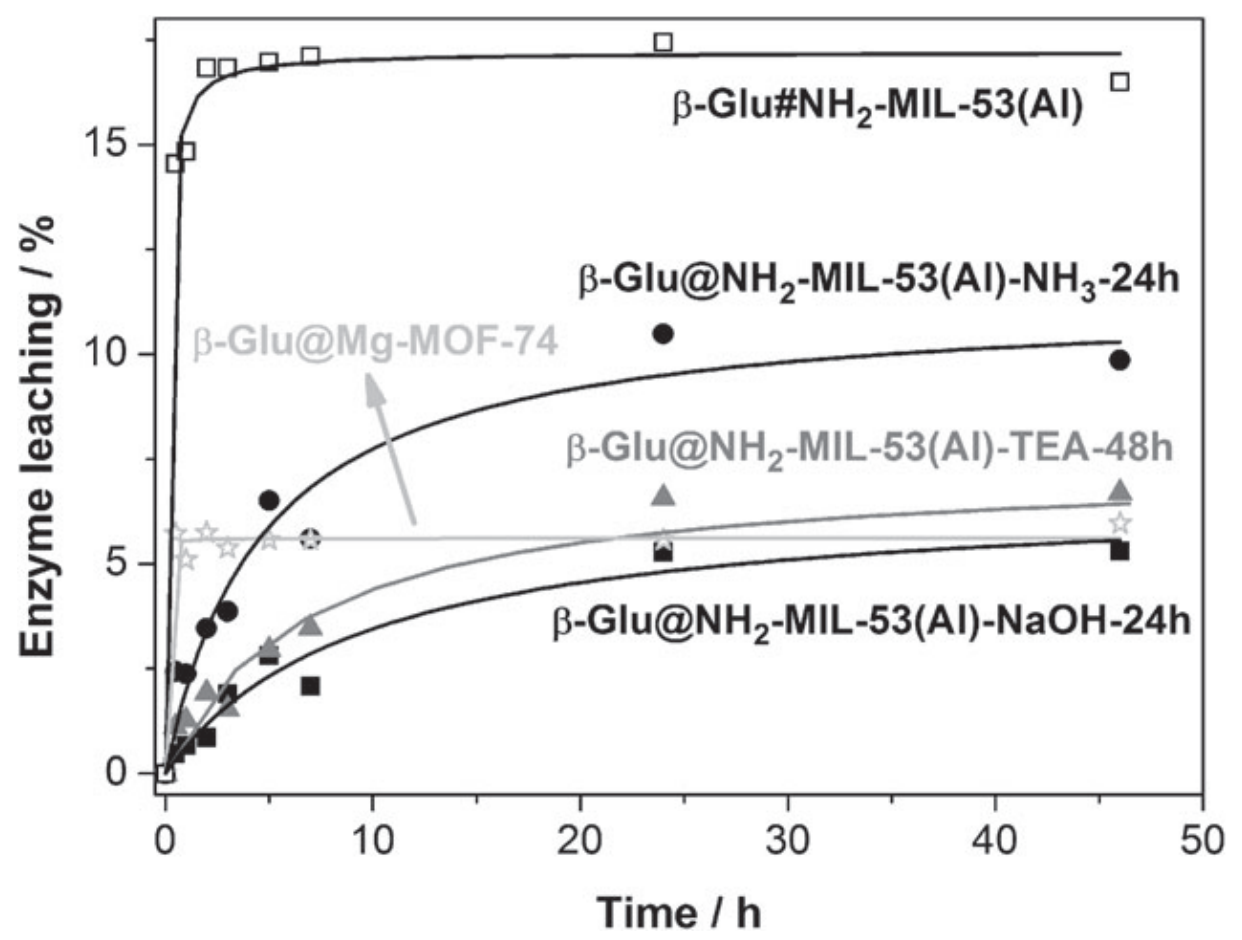

Figure 6. Percentage enzyme leaching of some $\beta$-glucosidase-containing biocatalysts of this work along the tested time (from top to bottom): post-synthesis $\beta$-Glu\#NH2-MIL-53(Al) and in situ $\beta$-Glu@NH2-MIL-53(Al)-NH3-24h, $\beta$-Glu@NH2MIL-53(Al)-TEA-48h, $\beta$-Glu@Mg-MOF-74, $\beta$-Glu@NH2-MIL-53(Al)-NaOH-24h. 
Post-synthesis vs in situ enzyme immobilization on nanocrystallineMOF supports One of the main strengths of this study is the diversity ofmethodologies proposed to immobilize enzymes on nanocrystallineMOFs after the study of a number of variables. Namely, post-synthesis and in situ strategies, synthesis medium either aqueous or adverse organic solvent (DMF), two enzymes with different size/affinities and MOF supports with different physico-chemical properties (functionalization, pore size, etc.). Having discussed these strategies during this article, it seems noteworthy to make a systematic comparison between post-synthesis and in situ strategies. To this aim, three key aspects of the enzyme immobilization will be discussed: enzyme leaching, enzyme loading and catalytic activity

The representative biocatalysts selected were post-synthesis $\beta$-Glu\#NH2-MIL-53(Al) (entry 1 of Table 1 ) and in situ $\beta$-Glu@NH2-MIL-53(Al)-TEA-48h (entry 4 of Table 2). Figure 6 shows the leaching of $\beta$ glucosidase from the different MOF. All the biocatalysts share the same shape with an initial desorption during the first hours of treatment, and then a plateau is reached. Longer incubation times showed no further increase of leached protein. Probably, the initial desorption observed is mainly due to the removal of enzyme molecules immobilized on the external surface of the MOF particles. However, the amount of released $\beta$-glucosidase from post-synthesis $\beta$-Glu\#NH -MIL-53(Al) is significantly higher than from in situ ones, as expected from the encapsulation model assumed from the results presented along this work.40,41 This is especially evident for $\beta$-Glu@NH2-MIL-53(Al)-TEA-48h, where the immobilization yield is as high as 99\% (see Table 2).

The immobilization method also has different effects on the catalytic activity. As seen in entry 1 of Table 1 and entry 4 of Table 2 , the activity of $\beta$-glucosidase is better preserved via post-synthesis immobilization (19.30 units per milligram of immobilized enzyme). This is an expected result since the immobilization medium is mild whereas in situ immobilization is performed in less favorable conditions for enzymatic activity.

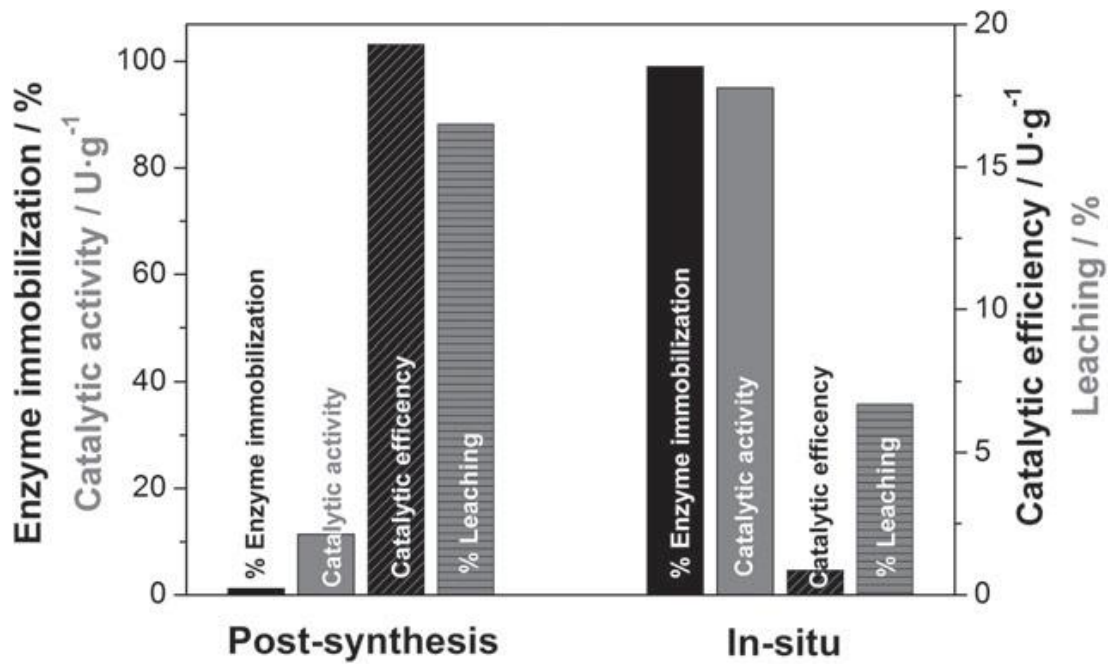

Figure 7. Percentage enzyme immobilization (black columns, left $Y$-axis), catalytic activity (grey, left $Y$-axis), catalytic efficiency (striped black, right $Y$-axis) and percentage enzyme leaching (striped grey, right $Y$-axis) of the biocatalyst $\beta$ Glu\#NH2-MIL-53(Al) prepared by post-synthesis (left) and in situ (right) approaches.

Figure 7 graphically compares the most remarkable catalytic data of the two selected biocatalysts in the hydrolysis of the p-NPG to p-nitrophenol at $35 \circ \mathrm{C}$. At first glance, the marked differences between the catalytic performance of in situ and post-synthesis biocatalysts are very clear. Thus, enzyme immobilization yield (black columns in Fig. 7) ismuchhigherwhen the biocatalyst is prepared in situ, and is able to retain practically all available enzymes in the media for the studied enzyme concentrations. In contrast, in the post-synthesis approach, enzymes found restrictions to entering the cavities, which is logical paying attention to their dimensions $(12.3 \mathrm{~nm} \times 10.7 \mathrm{~nm} \times 8.1 \mathrm{~nm})$ and the pore size distribution of the $\mathrm{NH}_{2}-\mathrm{MIL}-53(\mathrm{Al})$ (centered at $7 \mathrm{~nm}$ ). As a result of the immobilization yield, catalytic activity considered in units per gram of biocatalyst of the in situ biocatalyst is much higher (grey columns in Fig. 7) than its post-synthesis counterpart, although the specific activity (units per mg of immobilized $\beta$ glucosidase, striped black columns in Fig. 7) of the in situ one was lower. Finally, as commented above, 
the leaching of $\beta$-glucosidase is three times lower in the in situ approach, retaining almost $93 \%$ of the enzyme immobilized (striped grey columns in Fig. 7).

\section{CONCLUSIONS}

Post-synthesis and in situ approaches to immobilize the enzymes $\beta$-glucosidase and (post-synthesis one for) laccase on sustainable MOF materials has been described and compared in this work. The studied MOF supports, $\mathrm{NH}_{2}$-functionalized and non-functionalized MIL-53(Al) and Mg-MOF-74, are characterized by two key features: (i) high external surface area (mainly as intercrystalline mesoporosity); and (ii) preparation at room temperature. Biocatalysts prepared in situ became richer in enzyme loadings ( $>85 \%$ of the enzyme added to the synthesis media), more catalytically active and leaked less of the immobilized enzymes, whereas the intrinsic catalytic activity per enzyme molecule was higher in the postsynthesis biocatalysts. The in situ approach even led to active biocatalysts in a non-aqueous adverse media for enzymes, N,N-dimethylformamide. These methods are of general application because the enzymes do not have to be smaller than the MOF pores. The wide structural, compositional and synthetic versatility of MOFs opens up many possibilities for their use as enzyme supports.

\section{ACKNOWLEDGEMENT}

This work has been partially financed by the Spanish State Research Agency (Agencia Española de Investigación, AEI) and the European Regional Development Fund (Fondo Europeo de Desarrollo Regional, FEDER) through the Project MAT2016-77496-R (AEI/FEDER, UE). The authors thank X. Xiao, T. Siepenkoetter and C. Carucci for critical comments on the manuscript. .

\section{REFERENCES}

1 Corma A, Nemeth LT, Renz M and Valencia S, Sn-zeolite beta as a heterogeneous chemoselective catalyst for Baeyer-Villiger oxidations. Nature 412:423-425 (2001).

2 Deluga GA, Salge JR, Schmidt LD and Verykios XE, Renewable hydrogen from ethanol by autothermal reforming. Science 303:993-997 (2004).

3 Vaughan BA, Webster-Gardiner MS, Cundari TR and Gunnoe TB, A rhodium catalyst for single-step styrene production from benzene and ethylene. Science 348:421-424 (2015).

4 Mosbach K, Methods in enzymology, in Immobilized Enzymes. Academic Press, New York (1976).

5 Sheldon RA, Enzyme immobilization: the quest for optimum performance. Adv Synth Catal 349:1289-1307 (2007).

6 Hanefeld U, Gardossi L and Magner E, Understanding enzyme immobilisation. Chem Soc Rev 38:453-468 (2009). 7 Mateo C, Palomo JM, Fernandez-Lorente G, Guisan JM and Fernandez-Lafuente R, Improvement of enzyme activity, stability and selectivity via immobilization techniques. Enzyme Microbiol Technol 40:1451-1463 (2007).

8 Verma ML, Barrow CJ and Puri M, Nanobiotechnology as a novel paradigm for enzyme immobilisation and stabilisation with potential applications in biodiesel production. Appl Microbiol Biotechnol 97:23-39 (2013).

9 Ansari SAand Husain Q, Potential applications of enzymes immobilized on/in nano materials: a review. Biotechnol Adv 30:512-523 (2012).

10 Tran DN and Balkus KJ Jr, Perspective of recent progress in immobilization of enzymes. ACS Catal 1:956-968 (2011).

11 Zhou Z and Hartmann M, Progress in enzyme immobilization in ordered mesoporous materials and related applications. Chem Soc Rev 42:3894-3912 (2013).

12 Garcia-Galan C, Berenguer-Murcia A, Fernandez-Lafuente R and Rodrigues RC, Potential of different enzyme immobilization strategies to improve enzyme performance. Adv Synth Catal 353:2885-2904 (2011).

13 Chaplin MF and Bucke C, Enzyme Technology. Cambridge University Press, 280 (1990).

14 Salis A, Meloni D, Ligas S, Casula MF, Monduzzi M, Solinas V et al., Physical and chemical adsorption of Mucor javanicus lipase on SBA-15 mesoporous silica. Synthesis, structural characterization, and activity performance. Langmuir 21:5511-5516 (2005).

15 Karagulyan HK, Gasparyan VK and Decker SR, Immobilization of fungal beta-glucosidase on silica gel and kaolin carriers. Appl Biochem Biotechnol 146:39-47 (2008).

16 Cao LQ, Immobilised enzymes: science or art? Curr Opin Chem Biol 9:217-226 (2005).

17 Mureseanu M, Galarneau A, Renard G and Fajula F, A newmesoporous micelle-templated silica route for enzyme encapsulation. Langmuir 21:4648-4655 (2005).

$18 \mathrm{Kim}$ J, Grate JW and Wang P, Nanostructures for enzyme stabilization. Chem Eng Sci 61:1017-1026 (2006).

19 Yang XY, Li ZQ, Liu B, Klein-Hofmann A, Tian G, Feng YF et al., 'Fish-in-net' encapsulation of enzymes in macroporous cages for stable, reusable, and active heterogeneous biocatalysts. Adv Mater 18:410-414 (2006). 20 Serra E, Mayoral A, Sakamoto Y, Blanco RM and Diaz I, Immobilization of lipase in ordered mesoporous materials: effect of textural and structural parameters. Micropor MesoporMater 114:201-213 (2008).

21 Serra E, Alfredsson V, Blanco RM and Diaz I, A comprehensive strategy for the immobilization of lipase in ordered mesoporous materials. Stud Sci Surf Catal 174:369-372 (2008).

22 Betancor $L$ and Luckarift HR, Bioinspired enzyme encapsulation for biocatalysis. Trends Biotechnol 26:566-572 (2008).

23 Hudson S, Cooney J and Magner E, Proteins in mesoporous silicates. Angew Chem Int Ed Eng 47:8582-8594 (2008).

24 Serra E, Diez E, Diaz I and Blanco RM, A comparative study of periodic mesoporous organosilica and different hydrophobic mesoporous silicas for lipase immobilization. Micropor Mesopor Mater 132:487-493 (2010). 25 Wiesbauer J, Bolivar JM, Mueller M, Schiller M and Nidetzky B, Oriented immobilization of enzymes made fit for applied biocatalysis: non-covalent attachment to anionic supports using Z(basic2) module. ChemCatChem 3:1299-1303 (2011). 
26 Santalla E, Serra E, Mayoral A, Losada J, Blanco RM and Diaz I, In situ immobilization of enzymes in mesoporous silicas. Solid State Sci 13:691-697 (2011).

27 Schoffelen S and van Hest JCM, Multi-enzyme systems: bringing enzymes together in vitro. Soft Matter 8:1736-1746 (2012).

28 Sheldon RA and van Pelt S, Enzyme immobilisation in biocatalysis:why, what and how? Chem Soc Rev 42:6223$6235(2013)$

29 Gascón V, Márquez-Álvarez C and Blanco RM, Efficient retention of laccase by non-covalent immobilization on amino-functionalized ordered mesoporous silica. Appl Catal A 482:116-126 (2014).

30 MayoralA,Gascon V, Blanco RM,Marquez-AlvarezCand Diaz I, Location of laccase in ordered mesoporous materials. APL Mater 2:7 (2014).

31 Kuppler RJ, Timmons DJ, Fang Q-R, Li J-R, Makal TA, Young MD et al., Potential applications ofmetal-organic frameworks. Coord ChemRev 253:3042-3066 (2009).

32 Issue 2 Chem Rev 112:673-1268 (2012).

33 Issue 16 Chem Soc Rev 43:5403-6176 (2014).

34 Furukawa H, Cordova KE, O'Keeffe M and Yaghi OM, The chemistry and applications of metal-organic frameworks. Science 341:1230444-1230412 (2013).

35 Ricco R, Pfeiffer C, Sumida K, Sumby CJ, Falcaro P, Furukawa S et al., Emerging applications of metal-organic frameworks. CrystEng- Comm 18:6532-6542 (2016).

36 Larsen RW, Wojtas L, Perman J, Musselman RL, Zaworotko MJ and Vetromile CM, Mimicking heme enzymes in the solid state: metal-organic materials with selectively encapsulated heme. J AmChemSoc 133:10356-10359 (2011).

37 Lykourinou V, Chen Y,Wang XS,Meng L, Hoang T,Ming LJ et al., Immobilization of MP-11 into a mesoporous metalorganic framework, MP-11@mesoMOF: a new platform for enzymatic catalysis. J Am Chem Soc 133:10382-10385 (2011).

38 Chen Y, Lykourinou V, Hoang T, Ming LJ and Ma S, Size-selective biocatalysis of myoglobin immobilized into a mesoporous metal-organic framework with hierarchical pore sizes. Inorg Chem 51:9156-9158 (2012).

39 Raja DS, Liu W-L, Huang H-Y and Lin C-H, Immobilization of protein on nanoporous metal-organic framework materials. Comment Inorg Chem 35:331-349 (2015).

$40 \mathrm{Wu}$ X, Hou M and Ge J, Metal-organic frameworks and inorganic nanoflowers: a type of emerging inorganic crystal nanocarrier for enzyme immobilization. Catal Sci Technol 5:5077-5085 (2015).

41 Mehta J, Bhardwaj N, Bhardwaj SK, Kim K-H and Deep A, Recent advances in enzyme immobilization techniques: metal-organic frameworks as novel substrates. Coord Chem Rev 322:30-40 (2016).

42 Juan-Alcañiz J, Ramos-Fernandez EV, Kapteijn F and Gascon J, CHAPTER 10. MOFs as nano-reactors, in Metal Organic Frameworks as Heterogeneous Catalysts, ed by Llabres i Xamena F and Gascon J. Royal Society of Chemistry, 310-343 (2013)

43 Gkaniatsou E, Sicard C, Ricoux R, Mahy JP, Steuno N and Serre C, Metal-organic frameworks: a novel host platform for enzymatic catalysis and detection, Mater Horizon 4:55-63 (2017).

44 Chen Y, Lykourinou V, Vetromile C, Hoang T, Ming LJ, Larsen RW et al., How can proteins enter the interior of a MOF? Investigation of cytochromec translocation into aMOF consisting of mesoporous cages with microporouswindows. J AmChem Soc 134:13188-13191 (2012).

45 Deng H, Grunder S, Cordova KE, Valente C, Furukawa H, Hmadeh M et al., Large-pore apertures in a series of metal-organic frameworks. Science 336:1018-1023 (2012).

46 Ma S,Ming LJ, Chen Y and Lykourinou V,WOPatent 2012174402 (2012).

47 Feng D, Liu TF, Su J, Bosch M, Wei Z, Wan W et al., Stable metal-organic frameworks containing single-molecule traps for enzyme encapsulation. Nat Commun 6:1-8 (2015).

48 Lian X, Chen Y-P, Liu T-F and Zhou H-C, Coupling two enzymes into a tandem nanoreactor utilizing a hierarchically structured MOF. Chem Sci (2016).

49 Shih $Y-H$, Lo S-H, Yang N-S, Singco B, Cheng Y-J, Wu C-Y et al., Trypsin-immobilized metal-organic framework as a biocatalyst in proteomics analysis. ChemPlusChem 77:982-986 (2012).

50 Liu W-L, Lo S-H, Singco B, Yang C-C, Huang H-Y and Lin C-H, Novel trypsin-FITC@MOF bioreactor efficiently catalyzes protein digestion. JMater Chem B 1:928-932 (2013).

51 LiuWL,Wu CY, Chen CY, Singco B, Lin CH and Huang HY, Fast multipoint immobilized MOF bioreactor. Chem Eur J 20:8923-8928 (2014).

52 LiuWL, Yang NS, Chen YT, Lirio S,Wu CY, Lin CH et al., Lipase-supported metal-organic framework bioreactor catalyzes warfarin synthesis. Chem Eur J 21:115-119 (2015).

53 Wang $X$, Makal TA and Zhou H-C, Protein immobilization in metal-organic frameworks by covalent binding. Aust $J$ Chem 67:1629-1631 (2014).

54 Shieh FK, Wang SC, Yen CI, Wu CC, Dutta S, Chou LY et al., Imparting functionality to biocatalysts via embedding enzymes into nanoporous materials by a de novo approach: size-selective sheltering of catalase in metal-organic framework microcrystals. J Am Chem Soc 137:4276-4279 (2015).

55 Liang K, Ricco R, Doherty CM, Styles MJ, Bell S, Kirby N et al., Biomimetic mineralization of metal-organic frameworks as protective coatings for biomacromolecules. Nat Commun 6:1-8 (2015).

56 Lyu F, Zhang Y, Zare RN, Ge J and Liu Z, One-pot synthesis of protein-embedded metal-organic frameworks with enhanced biological activities. Nano Lett 14:5761-5765 (2014).

57 Chulkaivalsucharit P, Wu X and Ge J, Synthesis of enzyme-embedded metal-organic framework nanocrystals in reverse micelles. RSC Adv 5:101293-101296 (2015).

58 Stock N and Biswas S, Synthesis of metal-organic frameworks (MOFs): routes to various MOF topologies,

morphologies, and composites. Chem Rev 112:933-969 (2012).

59 Sanchez-Sánchez M, Díaz I, Getachew N and Chebude Y, ES Patent P201231968, (2012).

60 Sánchez-Sánchez M, Getachew N, Díaz K, Díaz-García M, Chebude Y and Díaz I, Synthesis ofmetal-organic frameworks in water at room temperature: salts as linker sources. Green Chem 17:1500-1509 (2015).

61 Ruano D, Díaz-García M, Alfayate A and Sánchez-Sánchez M, Nanocrystalline M-MOF-74 as heterogeneous catalysts in the oxidation of cyclohexene: correlation of the activity and redox potential. Chem- CatChem 7:674-681 (2015).

62 Díaz-García M, Mayoral Á, Díaz I and Sánchez-Sánchez M, Nanoscaled M-MOF-74 materials prepared at room temperature. Cryst Growth Des 14:2479-2487 (2014). 
$63 \mathrm{Wu}$ X, Ge J, Yang C, Hou M and Liu Z, Facile synthesis of multiple enzyme-containing metal-organic frameworks in a biomolecule-friendly environment. Chem Commun 51: 13408-13411 (2015).

64 Chen Y and Ma S, Biomimetic catalysis of metal-organic frameworks. Dalton Trans 45:9744-9753 (2016).

65 Sontz PA, Bailey JB, Ahn S and Tezcan FA, A metal organic framework with spherical protein nodes: rational chemical design of 3D protein crystals. J AmChemSoc 137:11598-11601 (2015).

66 Fujita D and Fujita M, Fitting proteins into metal organic frameworks. ACS Cent Sci 1:352-353 (2015).

$67 \mathrm{Wu} X$, Yang C, Ge J and Liu Z, Polydopamine tethered enzyme/metal-organic framework composites with high stability and reusability. Nanoscale 7:18883-18886 (2015).

68 Shi J, Wang X, Zhang S, Tang L and Jiang Z, Enzyme-conjugated ZIF-8 particles as efficient and stable Pickering interfacial biocatalysts for biphasic biocatalysis. JMater Chem B 4:2654-2661 (2016).

69 Zhao M, Zhang X and Deng C, Rational synthesis of novel recyclable Fe(3)O(4)@MOF nanocomposites for enzymatic digestion. Chem Commun (Camb) 51:8116-8119 (2015).

70 Castro-Miguel E, Gascón V, Sánchez-Sánchez M, Blanco RM and Díaz-García M, PCT/ES2016/070397, WO Patent 2016193516 A1 (2016).

71 Bradford MM, Rapid and sensitive method for quantitication of microgram quantities of proetien utiliaing principel of protein-dye binding. Anal Chem 72:248-254 (1976).

72 Gascon V, Diaz I, Blanco RM and Marquez-Alvarez C, Hybrid periodic mesoporous organosilica designed to improve the properties of immobilized enzymes. RSC Adv 4:34356-34368 (2014).

73 Villarroel-Rocha J, Barrera D and Sapag K, Introducing a self-consistent teHalenda method for pore-size determination.Micropor MesoporMater 200:68-78 (2014).

74 Sanchez-Sanchez M, de Asua I, Ruano D and Diaz K, Direct Synthesis, Structural features, and enhanced catalytic activity of the basolite F300-like semiamorphous Fe-BTC framework. Cryst Growth Des 15:4498-4506 (2015).

75 Agirre J, Ariza A, Offen WA, Turkenburg JP, Roberts SM, McNicholas S et al., Three-dimensional structures of two heavily N-glycosylated Aspergillus sp. family GH3 $\beta$-D-glucosidases. Acta Crys D72:254-265 (2016).

76 Urrego S, Serra E, Alfredsson V, Blanco RM and Diaz I, Bottle-around-the-ship: a method to encapsulate enzymes in ordered mesoporous materials. Micropor Mesopor Mater 129: 173-178 (2010).

77 Chen Y, Han S, Li X, Zhang Z and Ma S, Why does enzyme not leach from metal-organic frameworks (MOFs)? Unveiling the interactions between an enzyme molecule and a MOF. Inorg Chem 53:10006-10008 (2014).

78 Cao L, Langen Lv and Sheldon RA, Immobilised enzymes: carrier-bound or carrier-free? Curr Opin Biotechnol 14:387-394 (2003).

79 Laemmli UK, Cleavage of structural proteins during the assembly of the head of bacteriophage T4. Nature 227:680685 (1970). 
